\title{
The Importance of Service Experience, Trust, and Satisfaction on Banking Customer Loyalty
}

\author{
Desia Indriastuti and Anas Hidayat
}

\section{ABSTRACT}

This research aims to analyze service experience and trust on satisfaction, analyze service experience and trust on loyalty as well as to analyze the effect of satisfaction on loyalty. This research was conducted by taking credit customers from Bank Rakyat Indonesia in Yogyakarta, a special big city in Indonesia. This research has utilized a purposive sampling technique. The number of samples as respondents in the study were 250 people. The calculation technique used in this study is the AMOS Structural Equation Modeling. The results showed that there are significant influence of Service Experience and Trust on Satisfaction; and also, there are significant influence of Service Experience, Trust and Satisfaction on Loyalty. Based on direct and direct effects analysis among independent variables, Customer Satisfaction is found as a significant role of mediating, since total effects of Service Experiences and Trust toward Customer loyalty are bigger results than their direct effects.

Keywords: Service Experiences, Trust, Customer Satisfaction, Customer Loyalty, Bank Rakyat Indonesia.

\author{
Submitted : April 27, 2021 \\ Published : May 18, 2021 \\ ISSN: $2507-1076$ \\ DOI: $10.24018 /$ ejbmr.2021.6.3.864 \\ Desia Indriastuti \\ Magisters Management Program, Faculty \\ of Business and Economics, Universitas \\ Islam Indonesia, Indonesia. \\ (e-mail: kumaladian12@gmail.com) \\ Anas Hidayat* \\ Magisters Management Program, Faculty \\ of Business and Economics, Universitas \\ Islam Indonesia, Indonesia. \\ (e-mail: anas.hidayat ${ }^{@}$ uii.ac.id)
}

*Corresponding Author

\section{INTRODUCTION}

Customer loyalty is essential for the company because it is a valuable asset that can provide large profits for the company so that it can help the company in achieving competitive advantage [1]. Customer loyalty is very important for banks that maintain business continuity. Ishak dan Lutfi [2] explained that consumer loyalty is a manifestation and continuation of consumer satisfaction in using the facilities and services provided by the company, and to remain a consumer of the company. As stated by Singh [3], that satisfaction is a factor that directly influences consumer loyalty. Nowadays customer satisfaction is the focus of attention by almost all parties, government, business, consumers and so on. This is due to their better understanding of the concept of customer satisfaction as a strategy to win competition in the business world. Customer satisfaction is important for service providers because customers will disseminate their satisfaction to prospective customers, thereby promoting the reputation of service providers.

The relationship between customer satisfaction and customer loyalty has been widely studied in several studies. Fornell [4] states that customer satisfaction affects buying behavior, where satisfied customers tend to be loyal customers, but loyal customers need not be satisfied. Loyalty means the company's ability to position its products in the minds of customers, where the company tries to regard customers as partners by strengthening customer trust, always interacting, and developing for mutual progress if necessary [5]. Customer satisfaction is determined by the quality of the products and services that the customer wants, so that quality assurance becomes the main priority for the bank. For customer satisfaction with services, there are two main things that are closely interrelated namely customer expectations of service quality (expected quality) and customer perceptions of service quality (perceived quality). The customer always evaluates a service received compared to what is expected or desired [6]. Customer satisfaction must be accompanied by customer loyalty. Customer satisfaction concerns what is expressed by customers about their perceptions and expectations of banking services obtained from banks. [7] revealed that a good customer experience leads to customer loyalty. [8] concluded that customer experience involves total participation in the customer's life cycle, during the search, consumption, purchase, and after-sales phase of experience, which is measured against customer expectations and will ultimately increase customer retention and customer loyalty which conclusively influence business value.

According to Ishak and Lutfi [2], consumer trust in brands is an important factor that can build loyalty. Tjahjadi [9] also states, to gain loyalty in the current market, marketers must focus on forming and maintaining trust in customer relationships with brands. Consumer trust is an important factor for realizing customer loyalty. Nasution and Widjajanto [10] citing various expert opinions, states that trust translated as trust is an important prerequisite in business interactions. It becomes a basis for someone or a company to conduct business transactions with other people or companies. Business transactions will not occur if the threshold of trust is not reached among the business people.

This research takes the object on the consumer of Bank Rakyat Indonesia (BRI) in Yogyakarta. This city has been famous as a tourism destination in Indonesia. A lot of SME's work for tourism services. The reason for taking the object of 
the research is because BRI emphasizes micro-lending for SME's. However, BRI consistently focuses mostly on local entrepreneurs in remote rural areas. This research become interesting since it will recognize their rural customer responses rather than their remote rural customers. To be able to provide high quality services for better quality and better customer satisfaction in their rural operation, BRI prioritizes customer-focused services. Therefore, BRI is close to its customers. Servicing SME's customers in fact is not easy, because it has to compete with other banks, mostly small banks or financial services agents that provide fast micro finance services.

For this matter above, the research objectives are reasonable for expecting to identify and to analyze the effect of service experience, trust, and satisfaction on customer.

\section{THEORETICAL FRAMEWORK}

\section{A. Customer Loyalty}

Loyalty is literally interpreted as quality of being loyal or faithful, that is, one's loyalty to an object. According to Jumaev et al. [1] customer loyalty is a customer who not only repurchases goods and services, but also has a positive commitment and attitude towards service companies, for example by recommending others to buy. Furthermore, according to Velnampy and Sivesan [11], customer loyalty is a habit of repetitive buying behavior, high connection, and affiliation in their choices, and is characterized by external information seeking and alternative evaluation. Many experts believe that one of the keys to marketing is to build strong customer relationships on an ongoing basis. The impact of customer relationship management is to increase customer loyalty to the company. In the marketing concept, customer loyalty is a very important concern for managers in order to maintain the survival of customers. In a competitive environment, customer relationship becomes an important issue for decision making in order to realize competitive advantage [12].

However, the concept of customer relations is relatively difficult to apply in order to maintain and gain customer loyalty in a competitive marketing environment. Consequently, to maintain high customer loyalty, decision makers must pay more in an effort to maintain good customer relations, and this is the main goal of customer management [13].

\section{B. The Influence of Service Experience on Satisfaction}

Rose et al. [14] stated that in order to increase consumer satisfaction in purchasing, marketers need to know the customer's experience in doing the buying process. Satisfaction includes one's feelings in making a purchase. If someone is satisfied with a purchase that has been made, then it is likely to make a repurchase at the same place. Experience is the best variable for predicting future behavior. The customer's experience in purchasing has a significant influence on repurchase intentions [15]. Satisfaction is believed to influence attitudes and consumers after making a purchase to repurchase a product or reuse a service. Customer satisfaction is the accumulation of attitude and experiencebased [4]. Customers must be satisfied with the buying experience because if they are not satisfied, they will not shop again [16]. A positive experience will likely make the seller gain the trust of the customer. Experience shows that it positively influences the customer's intention to buy a product or service [17]. In marketing the important thing that concerns consumers is the experience of previous purchases. This is related to customer satisfaction and the impact on purchases [18].

\section{H1: There is a Significant Influence of Service Experiences on Satisfaction}

\section{The Influence of Trust on Satisfaction}

Trust is seen as one of the fundamental and important things in the business world. According to Singh and Sirdeshmukh [19], trust is the foundation in building and maintaining long-term relationships. Trust in marketing theory is the basis for developing and maintaining long-term relationships [20], creating mutually beneficial relationships with customers and increasing competitiveness [21]. Trust is an important factor that can overcome the crisis and difficulties between business partners, but it is also an important asset in developing long-term relationships between organizations [22]. Organizations that are able to recognize and control the factors forming trust, can create and streamline the level of relationships with customers [21].

\section{H2: There is a Significant Influence of Trust on Satisfaction}

\section{The Influence of Service Experience on Loyalty}

Research conducted by Zyung et al. [23] explains that there is a significant influence between service experiences on customer loyalty. Their research findings are also supported by Azhari et al. [24] which explains the significant influence of customer experience on customer loyalty. Further studies related to the relationship between customer experience and customer loyalty were also conducted by Klaus and Maklan [25] where they found the fact that service experience also had a significant impact on customer loyalty, thus creating a superior customer experience (superior customer experience) has become the main goal companies in the service sector in their efforts to build customer loyalty. Management of service experience here is important to improve relationships with customers and build customer loyalty [26]. Hence based on a study of Zyung et al. [23], Azhari et al. [24], Klaus and Maklan [25], and Chauhan and Manhas [26], it can be said that service experience affects customer loyalty.

\section{H3: There is a Significant Influence of Service Experience on Loyalty}

\section{E. The Influence of Trust on Loyalty}

Trust is considered the most important way to build and maintain relationships with customers in the long run. Trust arises from a long process until both parties trust each other. If trust has arisen between the company and the customer, then the effort to foster cooperation will be easier so that it 
will benefit both parties. Building trust and credibility cannot be done in an instant. To strengthen trust, risk is needed to be open with the public and clients. When trust is reciprocal, confidence will be found between the two parties. The higher the level of trust given to members, the higher the level of loyalty [27].

\section{H4: There is a Significant Effect of Trust on Loyalty}

\section{F. The Influence of Satisfaction on Loyalty}

The relationship between customer satisfaction and customer loyalty has been widely studied in several studies. Fornell [4] says that customer satisfaction affects buying behavior, where satisfied customers tend to be loyal customers, but loyal customers need not be satisfied. Loyalty means the company's ability to position its products in the minds of customers, where the company tries to regard customers as partners by strengthening customer trust, always interacting, if necessary, developing for mutual progress [5]. The attitude of loyal customers is influenced by the beliefs, emotions and feelings of satisfaction and expectations of the customers themselves. Besides that, the bank must be able to turn satisfaction into contentment. For the bank this is a challenge to create a special relationship between the customer and the bank which will be profitable in the long run. The person-to-person approach taken by the bank allows the bank to hear and know that its service offer is supportive or in accordance with the needs/expectations of the customer and can immediately respond to customer requests and complaints.

H5: There is a Significant Influence of Satisfaction on Loyalty

\section{RESEARCH MODEL}

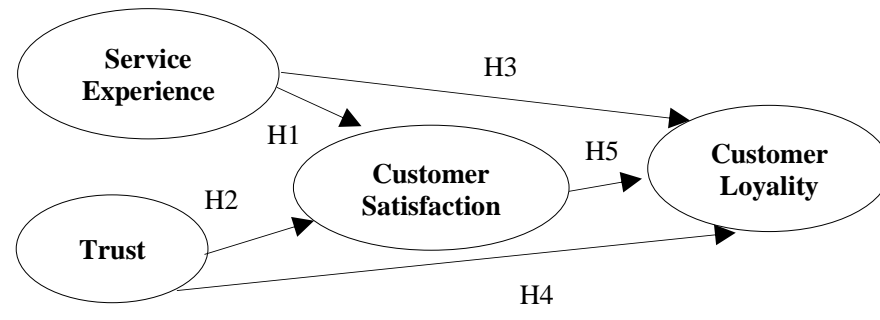

Fig. 1. Research Model.

\section{RESEARCH METHODS}

The type of this research is survey research, which is systematic collection of information from respondents with a view to understanding and or predicting some aspects of the behavior of the observed population. The study was conducted by taking a borrowing customer at the Bank Rakyat Indonesia Ambarukmo Unit Adisucipto Branch in Yogyakarta with sampling using a purposive sampling technique. The number of samples determined in this study as many as 250 people, due to time and cost limitations, has met the assumptions of using AMOS SEM. The calculation technique used in this study is the Structural Equation Modeling AMOS.

\section{DATA ANALYSIS}

This study uses primary data obtained from the responses of 250 respondents as the research sample through a questionnaire. The responses from these respondents will later become information to answer the problems that have been addressed in the previous chapter.

\section{A. Descriptive Statistical Analysis}

Based on the findings of the descriptive analysis of the respondents' identity, the author found several characteristics that influence service experience, trust, customer satisfaction and customer loyalty. The majority of respondents were in productive age (31-40 years) and the respondents with Bachelor degree were the largest. In addition, the majority of respondents' occupations were self-employed. Meanwhile, from the description of research variables, the variables of service experience, trust, customer satisfaction, and customer loyalty have high scores, respectively: $4.47 ; 4,50 ; 4.36$; and 4.52. This score means that each variable is in the "strongly agree" category.

\section{B. Quantitative Analysis}

Following the statistical descriptive analysis, the author conducted a quantitative analysis using the multivariate statistical method of Structural Equation Modeling (SEM) using AMOS 23 software. The author tested the model by estimating the model from existing data as follows:

\section{Outlier Test}

The results of the outlier test using analysis of the multivariate outliers can be seen from the Mahalanobis Distance value calculated using the chi-square value of the degree of freedom of 21 indicators at the $p<0.001$ level using the formula X2 $(21 ; 0.001)=46.962$. The results of the outlier analysis show that there are four outlier data that must be eliminated from the analysis. After the data were eliminated, the data were analyzed again and it is known that the highest Mahalanobis Distance Square value is 37.143, so it does not exceed the c-square value of 38.9. From these results, it can be concluded that the data do not contain outliers.

\section{Data Normality Test}

Normality testing is carried out by observing the value of the Critical Ratio (CR) of the data used. If the CR value of the multivariate data is between \pm 2.58 , the research data can be considered normal. The results of the data normality test showed that the CR value of the multivariate data was 2.337 which means it was below 2.58. So that the data in this study can be considered as normally distributed.

\section{Confirmatory Analysis}

Confirmatory analysis in this study was used to test the concept that was built using several measurable indicators. The first thing seen in the confirmatory analysis is the loading factor value of each indicator.

\section{Validity Test}

Loading factor can be used to measure the validity of the construct where a questionnaire is said to be valid if the 
questions on the questionnaire are able to reveal something that is measured by the questionnaire. According to Hair et al. [28], the minimum number of factor loading is $\geq 0.5$ or ideally $\geq 0.7$. If there is a value that is still below 0.5 it will be excluded from the analysis. With the loading factor value in Table I.

\begin{tabular}{|c|c|c|c|}
\hline Indicator & Average & Validity & Reliability \\
\hline Service Experience & 4,20 & & \multirow{8}{*}{0,9} \\
\hline Complete bank service features & 4,04 & 0,756 & \\
\hline Bank service suitability & 4,28 & 0,846 & \\
\hline $\begin{array}{l}\text { The pleasure of using bank } \\
\text { services }\end{array}$ & 4,18 & 0,776 & \\
\hline Ease of bank services & 4,16 & 0,804 & \\
\hline $\begin{array}{l}\text { Comparison of the value of } \\
\text { benefits perceived by customers }\end{array}$ & 4,24 & 0,834 & \\
\hline $\begin{array}{l}\text { Exploration of clarity of bank } \\
\text { information }\end{array}$ & 4,24 & 0,695 & \\
\hline $\begin{array}{l}\text { Special experience of bank } \\
\text { promo offers }\end{array}$ & 4,24 & 0,734 & \\
\hline Trust & 4,15 & & \multirow{7}{*}{0,9} \\
\hline $\begin{array}{l}\text { Banks are very concerned about } \\
\text { security when making } \\
\text { transactions }\end{array}$ & 4,17 & 0,711 & \\
\hline $\begin{array}{l}\text { The bank promises reliable } \\
\text { products and services }\end{array}$ & 4,15 & 0,794 & \\
\hline $\begin{array}{l}\text { The Bank is consistent in } \\
\text { providing quality services }\end{array}$ & 4,17 & 0,791 & \\
\hline $\begin{array}{l}\text { Bank employees show respect } \\
\text { for customers }\end{array}$ & 4,06 & 0,782 & \\
\hline $\begin{array}{l}\text { The bank fulfills its obligations } \\
\text { to customers }\end{array}$ & 4,18 & 0,847 & \\
\hline Customer Satisfaction & 4,17 & & \\
\hline $\begin{array}{l}\text { Ease of obtaining a product or } \\
\text { service }\end{array}$ & 4,12 & 0,567 & \multirow{6}{*}{0,8} \\
\hline $\begin{array}{l}\text { Compliance with product } \\
\text { specifications }\end{array}$ & 4,20 & 0,838 & \\
\hline Customer convenience & 4,20 & 0,840 & \\
\hline Level of customer complaints & 4,18 & 0,573 & \\
\hline Customer Loyalty & 4,19 & & \\
\hline $\begin{array}{l}\text { Make repeat purchases of bank } \\
\text { products and services } \\
\text { continuously }\end{array}$ & 4,19 & 0,721 & \\
\hline $\begin{array}{l}\text { Make transactions other than } \\
\text { saving money, such as paying } \\
\text { credit card bills, telephone bills, } \\
\text { or transfer services (rewards) }\end{array}$ & 4,23 & 0,769 & \multirow[t]{4}{*}{0,8} \\
\hline $\begin{array}{l}\text { Recommending bank products } \\
\text { and services to others } \\
\text { (recommendation) }\end{array}$ & 4,17 & 0,745 & \\
\hline $\begin{array}{l}\text { Not interested in switching to } \\
\text { another bank (refuse) }\end{array}$ & 4,26 & 0,599 & \\
\hline $\begin{array}{l}\text { Remain loyal to be a customer } \\
\text { of the bank }\end{array}$ & 4,11 & 0,159 & \\
\hline
\end{tabular}

From Table I it is known that all indicators in this study already have a loading factor value of more than 0.5 except Customer Loyaty Number 5 and must be dropped from the analysis. After dropping the invalid indicators, it can be concluded that all indicators in this study can be said to be valid.

\section{Reliability Test}

Based on the results of the Reliability Test, it is known that Construct Reliability (CR) of all variables showed a value of $\geq 0.7$. The Variance Extracted in each variable showed a value of $\geq 0.5$. So, it can be concluded that the questionnaire used in this study is reliable.

\section{Goodness of Fit Test}

Furthermore, the confirmatory model suitability test is tested using the Goodness of Fit Index. Hair et al. [28] divided the GOFI (Goodness of Fit Index) criteria into 3 types of criteria, namely absolute fit indices, incremental fit indices, and parsimony fit indices. Of the three types of GOFI, there are 25 criteria in total, however according to them above, in the SEM-Amos analysis does not require that all criteria be met, 4-5 criteria alone are sufficient as long as there are criteria that represent the three types of GOFI criteria.

In this study several criteria were taken from each type of GOFI, namely Chi-square, Probability, RMSEA and GFI representing absolute fit indices, CFI and TLI representing incremental fit indices, then PGFI and PNFI representing parsimony fit indices.

The results of the Goodness of Fit test show that there are two criteria in a non-fit condition, namely chi-square and probability, two criteria in a marginal fit condition and four criteria in a fit condition. So, it is necessary to adjust the model to increase the goodness of fit.

\section{Model Modification and Final Model Goodness of Fit Test}

Based on the tests that have been carried out, it can be seen that there are two criteria for poor fit, and four criteria for marginal fit. Therefore, the value of Goodness of Fit needs to be increased by implementing a model modification that refers to the table modification index by providing a covariance relationship or eliminating indicators that have a high Modification Index (MI) value.

After modification, the results show that the Goddness of Fit value has met all the criteria even though with 1 criterion it is still marginally fit, but according to Hair et al. [29] that the marginal fit value can still be tolerated so that the model in this study can be said to be Fit as in Table II and Fig. 2.

\begin{tabular}{ccccc}
\multicolumn{5}{c}{ TABLE II: GoOdNESS OF FIT AFTER MODIFICATION } \\
\hline \multirow{2}{*}{0} & $\begin{array}{c}\text { Goodness of } \\
\text { Fit }\end{array}$ & Kriteria & $\begin{array}{c}\text { Cut-off } \\
\text { value }\end{array}$ & Keterangan \\
\hline \multirow{3}{*}{ Absolute } & Chi-square & Kecil & 148,567 & Fit \\
Fit & Probability & $\geq 0.05$ & 0.093 & Fit \\
& RMSEA & $\leq 0.08$ & 0.026 & Fit \\
Incrementa & GFI & $\geq 0.90$ & 0,942 & Fit \\
1 Fit & TLI & $\geq 0.90$ & 0.992 & Fit \\
Parsimony & CFI & $\geq 0.90$ & 0.994 & Fit \\
Fit & PGFI & $\geq 0.60$ & 0.570 & Marginal Fit \\
\hline
\end{tabular}

The results of the analysis after modification show that there are seven fit criteria and one marginal fit. According to Hair et al. [28] the marginal value of fit can still be tolerated, so this research model can be considered fit.

\section{Hypothesis Testing}

The hypothesis in this study was tested using a full model Structural Equation Model (SEM) analysis. The results of the regression weight test in this study are as in Table III.

TABLE III: REGRESSION WEIGHT TEST RESULTS

\begin{tabular}{|c|c|c|c|c|c|c|}
\hline & & Estimate & S.E. & CR & $\mathrm{P}$ & Description \\
\hline$<---$ & SE & 0,665 & 0,058 & 11,383 & $* * *$ & Significant \\
\hline CS <--- & $\mathrm{T}$ & 0,062 & 0,026 & 2,381 & 0,017 & Significant \\
\hline CL <--- & SE & 0,739 & 0,070 & 10,502 & $* * *$ & Significant \\
\hline CL <--- & $\mathrm{T}$ & 0,093 & 0,027 & 3,456 & $* * *$ & Significant \\
\hline CL <--- & CS & 0,270 & 0,063 & 4,258 & $* * *$ & Significant \\
\hline
\end{tabular}

Note: Service Experience (SE); Trust (T); Customer Satisfaction (CS),

Customer Loyalty (CL). 


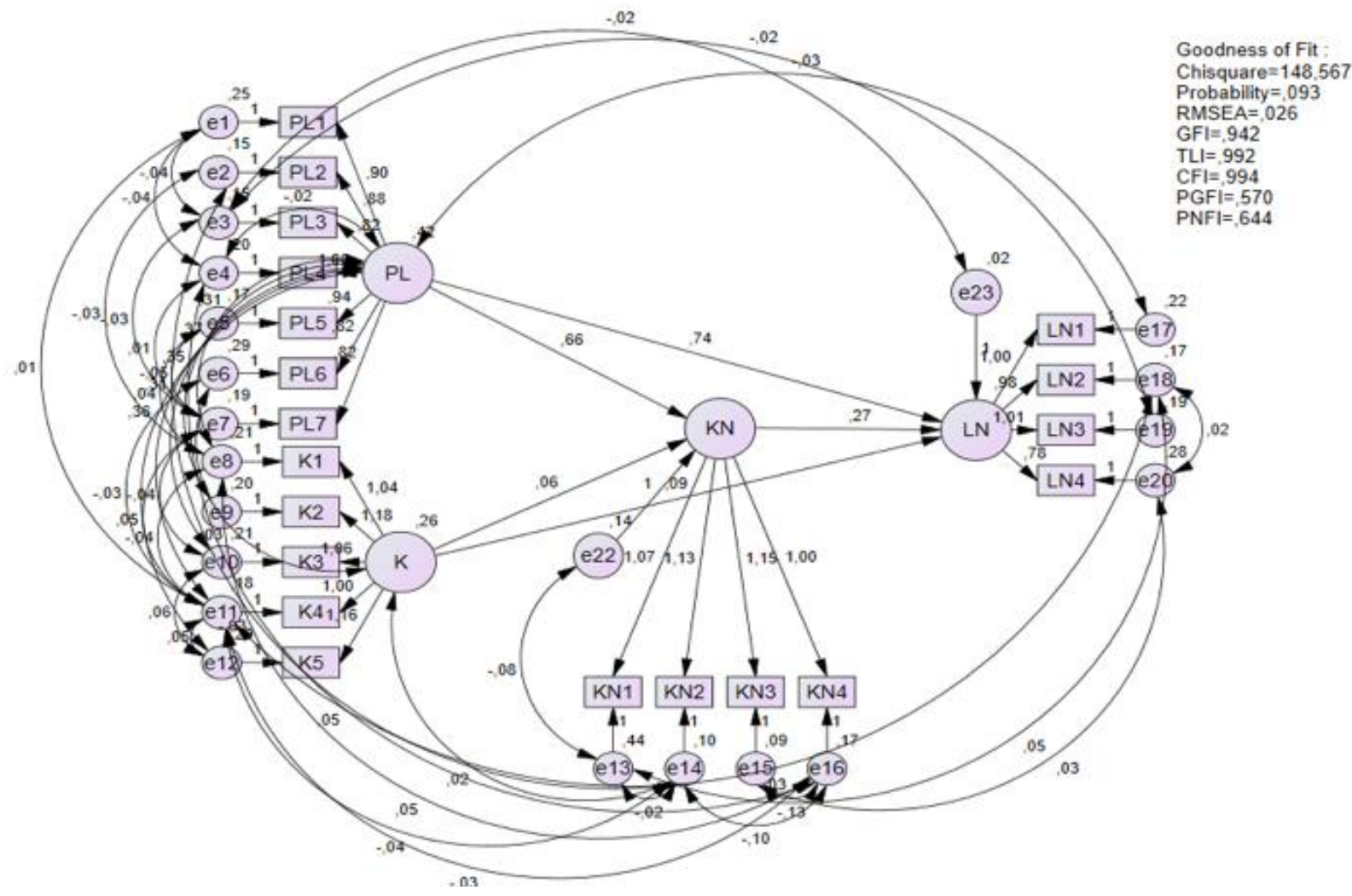

Fig. 2. Final Model Post Modification.

TABEL IV: DIRECT AND INDIRECT EFFECT OF INDEPENDENT VARIABLES

\begin{tabular}{cccccccccc}
\hline \multirow{2}{*}{ Variable } & \multicolumn{3}{c}{ Total Effects } & \multicolumn{3}{c}{ Direct Effects } & \multicolumn{3}{c}{ Indirect Effects } \\
\cline { 2 - 10 } & $\mathrm{T}$ & SE & CS & T & SE & CS & T & SE & CS \\
\hline CS & 0,06 & 0,67 & 0,00 & 0,06 & 0,67 & 0,00 & 0,00 & 0,00 & 0,00 \\
LN & 0,11 & 0,92 & 0,27 & 0,09 & 0,74 & 0,27 & 0,02 & 0,18 & 0,00 \\
\hline Source: processed data, 2021 & & & & & & &
\end{tabular}

The results of the analysis in the table above show that the hypothesis is strongly supported as indicated by the Critical Ratio $(\mathrm{CR})$ value above 1.96 and the Probability $(\mathrm{P})$ value below $0.05 / 5 \%$.

In term of direct and indirect effect analysis, the research model shows that Customer Satisfaction become a significant mediating for Service Experience and Trust toward Customer Loyalty. Result of total effects of Service Experiences as well as Trust on Customer Loyalty show 0,919 and 0,109. Their influences of both variables are less results when direct effects only showed 0,739 and 0,093. Table IV showed the direct and indirect effects among independent variables.

\section{DISCUSSION}

The model development in this study is based on the concept of data analysis. In general, this research model consists of 2 exogenous variables and 2 endogenous variables. The exogenous variables in this study were Service Experience (PL) and Trust (K). The endogenous variables in this study are Customer Satisfaction $(\mathrm{KN})$ and Customer Loyalty (LN). Based on the results of the estimation of the hypothesis testing model, the interpretation of each of the above hypothesis testing can be described as follows:

\section{A. First Hypothesis Testing}

The path coefficient (standardized estimate) of the estimated service experience to satisfaction is 0.665 . Based on the results of the coefficient significance test, the $C R$ value is 11.383 . The significance probability value is 0.000 , so the hypothesis at the 5\% significance level is accepted. Thus, the first hypothesis which states that there is a significant influence between service experience and satisfaction has been proven. This means that the higher service experience leads to higher customer satisfaction. Consistent with Fornell [4], customer satisfaction is an accumulated attitude and experience-based. Therefore, experience has a very positive effect on customer intentions to buy products or services [17], as well as customers must be satisfied with the buying experience because if they are not satisfied, they will not shop again [16].

\section{B. Second Hypothesis Testing}

The results of the estimation of trust that affect satisfaction obtained a path coefficient (standardized estimate) of 0.062 . The second hypothesis about trust influences satisfaction which is proven because through the significance test of this coefficient, the $\mathrm{CR}$ value is 2.381. The significance probability value is 0.017 , then the hypothesis at the $5 \%$ significance level is accepted. This means that the better customer trust, the higher the customer satisfaction is. This is because trust is the basis for building and maintaining long- 
term relationships [19]. This opinion is pointed out by Barney and Hansen [21], that organizations that are able to recognize and control the factors that form trust, can create and make effective levels of customer relationships.

\section{Third Hypothesis Testing}

The results of service experience estimation towards loyalty obtained a path coefficient (standardized estimate) of 0.739. With a CR value of 10,502 on the coefficient significance test and a significance probability value of 0,000 , the hypothesis at the $5 \%$ significant level is accepted. The third hypothesis is proven, that service experience affects customer loyalty. This is supported by Klaus and Maklan [25]; and Chauhan and Manhas [26], that service experience also has a significant impact on customer loyalty, thereby creating a superior customer experience.

\section{Fourth Hypothesis Testing}

The results of the estimation of trust affecting loyalty obtained a path coefficient (standardized estimate) of 0.093 . The CR value of the significance test of the $R$ coefficient is 3.456 , while the significance probability value is 0.000 , so the hypothesis at the $5 \%$ significant level is accepted, which means that trust has an effect on loyalty. Thus, hypothesis 4 which states that there is a significant influence between trust and loyalty is proven. According to Doney and Cannon [20], trust in marketing theory is the basis for policies to develop and maintain long-term relationships. Therefore, the better customer trust, the higher the customer loyalty is [27].

\section{E. Fifth Hypothesis Testing}

The results of the estimation of satisfaction affecting loyalty revealed path coefficient (standardized estimate) of 0.063 . The significance test of this coefficient obtained a CR value of 4.258 . The significance probability value is 0.005 , so the hypothesis at the $5 \%$ significant level is accepted, which means that satisfaction has an effect on loyalty. Thus, hypothesis 5 which states that there is a significant influence between satisfaction and loyalty is proven. This means that better customer satisfaction results in higher customer loyalty. Customer satisfaction affects buying behavior, where satisfied customers tend to be loyal customers [4], therefore companies try to think of customers as partners by convincing customers, always interacting, if necessary, developing for mutual progress [5].

The five hypotheses have been tested and proven, thus, service experience on satisfaction, trust on satisfaction, service experience on loyalty, trust on loyalty each has a significant effect. Optimal customer satisfaction encourages the creation of loyalty in the minds of customers. Customer loyalty is seen as the strength of the relationship between a person's relative attitude and repeat business. Loyalty is a strategic asset that a company has in several forms, such as reducing marketing costs, increasing transaction flows, attracting new customers, and giving time to respond to competitors' threats [30].

\section{CONCLUSION}

Based on the study above, it can be concluded that there is a Significant influence of Service Experience and Trust toward Satisfaction. Meanwhile, Service Experience, Trust and Satisfaction also have significant influences on Customer Loyalty separately. However, Service experience has the strongest influence on Customer Satisfaction and Customer Loyality. Interestingly, based on calculation of direct and indirect effects among variables, Customer Satisfaction has been a significant mediating, since all total effects of involved variables show bigger results than direct effect results.

Based on the results of the research above, apparently, Service Experience is an important variable in which the Bank Operators need to focus on it more. Even though Trust is not strong influence, but significant in this study. Probably, BRI customers do not see Trust is a main issue, since This bank is belonged to Indonesian Government, and also this bank is the top of three Banks in Indonesia. Moreover, Customer Satisfaction variable is still strong important to the Bank operation, and they need to concern on it. It is because Customer loyalty can be shaped by Customer Satisfaction, and it becomes the significant mediation for some independent variables. For this reason, for the future research, apparently, this research model can be extended more independent variables. If the future study still uses Indonesian Bank as a case study, it would be great when culture context as well as religiosity are involved. It is reasonable because Indonesia is colorful culture, many ethics, and believers.

\section{REFERENCES}

[1] Jumaev. M, D. K dan Jalal. R (2012). Impact of Relationship Marketing on Customer Loyalty in The Banking Sector. Far East Journal of Psychology and Business. 6 (3).

[2] Ishak, A., \& Luthfi, Z. (2011). Pengaruh kepuasan dan kepercayaan konsumen terhadap loyalitas: Studi tentang peran mediasi switching costs. Jurnal siasat bisnis, 15(1).

[3] Singh, J. (1991). Understanding the structure of consumers' satisfaction evaluations of service delivery. Journal of the academy of marketing science, 19(3), 223-244.

[4] Fornell, C. (1992). A national customer satisfaction barometer: The Swedish experience. Journal of marketing, 56(1), 6-21.

[5] Kertajaya, H. (2002). Marketing Plus: Siasat Memenangkan Persaingan Global. Jakarta: PT. Erlangga.

[6] [6] Parasuraman, A., Berry, L. L., \& Zeithaml, V. A. (1993). More on improving service quality measurement. Journal of retailing, 69(1), 140-147.

[7] Johansson, T., \& Kidron, T. (2017). Improving Customer Experience in Telecommunications Company. (Bachelor's Thesis, Laurea University of Applied Sciences).

[8] Sujata, J., Sanjay, B., Domb, M., Arindam, R., \& Jyoti, S. (2015, January). An Empirical Study to Measure Customer Experience for Telecom Operators in Indian Telecom Industry. In International Conference on Qualitative and Quantitative Economics Research $(Q Q E)$. Proceedings (p. 34). Global Science and Technology Forum.

[9] Tjahjadi, R. (2006). Suatu Tinjauan Mengenai Persepsi Mahasiswa Fakultas Ekonomi Universitas Maranatha Atas Program Experiental Marketing Indonesian Idol Terhadap Kepuasan Menonton Program Indonesian Idol (Doctoral dissertation, Universitas Kristen Maranatha).

[10] Nasution, R. A., \& Widjajanto, A. S. (2007). Proses Pembentukan Kepercayaan Konsumen: Studi Kasus Pada Sebuah Usaha Kecil Menengah Percetakan Digital Di Bandung. Journal of Technology Management, 6(2), 113832.

[11] Velnampy \& Sivesan. (2012). Customer Relationship Marketing and Customer Satisfaction: A Study on Mobile Service Providing Companies in Srilanka. Global Journal of Management and Business Research. 18 (1)

[12] Martini. K. (2013). Relationship Marketing, Customer Satisfaction, Customer Commitment dan Customer Loyalty (Studi Pada Sebuah Bank Nasional di Denpasar). Buletin Studi Ekonomi. 18 (1)

[13] Wang, J., \& Zhang, P. (2009). A discrete-time retrial queue with negative customers and unreliable server. Computers \& Industrial Engineering, 56(4), 1216-1222. 
[14] Rose, S., Clark, M., Samouel, P., \& Hair, N. (2012). Online customer experience in e-retailing: an empirical model of antecedents and outcomes. Journal of retailing, 88(2), 308-322.

[15] Huang, L., Yung, C. Y., \& Yang, E. (2011). How do travel agencies obtain a competitive advantage?: Through a travel blog marketing channel. Journal of Vacation Marketing, 17(2), 139-149.

[16] Kim, S., \& Stoel, L. (2004). Apparel retailers: website quality dimensions and satisfaction. Journal of retailing and consumer services, 11(2), 109-117.

[17] Chiu, C. Y., Chen, Y. F., Kuo, I. T., \& Ku, H. C. (2009). An intelligent market segmentation system using k-means and particle swarm optimization. Expert systems with applications, 36(3), 4558-4565.

[18] Zhou, K. Z., Brown, J. R., Dev, C. S., \& Agarwal, S. (2007). The effects of customer and competitor orientations on performance in global markets: a contingency analysis. Journal of International Business Studies, 38(2), 303-319.

[19] Singh, J., \& Sirdeshmukh, D. (2000). Agency and trust mechanisms in consumer satisfaction and loyalty judgments. Journal of the Academy of marketing Science, 28(1), 150-167.

[20] Doney, P. M., \& Cannon, J. P. (1997). An examination of the nature of trust in buyer-seller relationships. Journal of marketing, 61(2), 35-51.

[21] Barney, J. B., \& Hansen, M. H. (1994). Trustworthiness as a source of competitive advantage. Strategic management journal, 15(S1), 175190.

[22] Leninkumar, V. (2017). The relationship between customer satisfaction and customer trust on customer loyalty. International Journal of Academic Research in Business and Social Sciences, 7(4), 450-465.

[23] Zyung, J. D., Mittal, V., Kekre, S., Hegde, G. G., Shang, J., Marcus, B. S., \& Venkat, A. (2020). Service Providers' Decision to Use Ethics Committees and Consultation in Complex Services. Journal of Marketing Research, 57(2), 278-297.

[24] Azhari, A., Dalimin, M. N., \& Wee, S. T. (2011). Polycyclic aromatic hydrocarbons (PAHs) pollution from vehicle emission in the environment of highway roadside in Johor, Malaysia. In 2011 International Conference on Biotech. Environ. Manag. IPCBEE (Vol. $18)$.

[25] Klaus, P., Edvardsson, B., \& Maklan, S. (2012, May). Developing a typology of customer experience management practice-from preservers to vanguards. In 12th International Research Conference in Service Management, La Londe les Maures, France.

[26] Chauhan, V., \& Manhas, D. (2017). Dimensional analysis of customer experience in the civil aviation sector. Hospitality Marketing and Consumer Behavior. Creating Memorable Experiences, 75-10.

[27] Welta, F. (2017). Pengaruh Kualitas Layanan dan Kepercayaan terhadap Loyalitas Nasabah pada Baitul Maal Wat Tamwil (BMT) Surya Barokah. I-ECONOMICS: A Research Journal on Islamic Economics, 3(2), 129-148.

[28] Hair, J. F., Ringle, C. M., \& Sarstedt, M. (2011). PLS-SEM: Indeed, a silver bullet. Journal of Marketing theory and Practice, 19(2), 139152.

[29] Hair, J.F., Black, W.C., Babin, B.J., Anderson, R.E.(2010). Multivariate Data Analysis. 7th Edition. International Edition. England: Pearson Education Limited.

[30] Aaker, J. L. (1997). Dimensions of brand personality. Journal of marketing research, 34(3), 347-356.

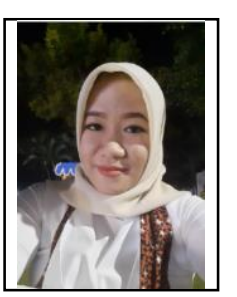

Desia Indriastuti is a student in Marketing in Magisters Management Program, Faculty of Business and Economics, Universitas Islam Indonesia. She completed Bachelor's degree in Faculty of Sociology Universitas Negeri Yogyakarta and continued the Magister degree in Faculty of Business and Economics, Universitas Islam Indonesia and concerned in marketing study.

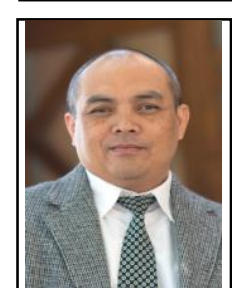

Anas Hidayat is An Associate Professor in Marketing at Magisters Management Program, Faculty of Business and Economics, Universitas Islam Indonesia. is a lecturer of management in Faculty of Economics and Business, Universitas Islam, Indonesia. He also completed his $\mathrm{Ph}$. D Degree in Marketing concerning on consumer behavior at Edith Cowan University, Western Australia. Currently $\mathrm{He}$ is still interested in consumer behavior since $\mathrm{He}$ believes that customers today may have more different views/beliefs due to many issues such as online business issue as well as Syariah/religious issue. Marketing in Service businesses also become his focusing because in global business today, their roles are more and more important. 